\title{
Filipino migrant workers' leisure and subjective quality of life in Macao
}

Jaeyeon Choe, Michael O’ Regan \& Albert N. Kimbu (2020) Filipino migrant workers' leisure and subjective quality of life in Macao, World Leisure Journal, DOI:

$10.1080 / 16078055.2020 .1798052$

\begin{abstract}
Utilizing 14 semi-structured interviews in a non-western context, this exploratory study examines how Filipino migrant workers' leisure satisfaction and QoL are intertwined in Macao, China. The study reveals that Filipino migrant workers regard "family and friends", and a sense of community as central to their QoL. Regarding leisure, the Filipino migrant workers experienced a lack of time-off and long working hours (structural leisure constraints) whilst living without their families in the Philippines (interpersonal leisure constraints). In addition, the Filipino migrant workers noted that few leisure options were available to them, and given commercial options dominate in Macao, the perceived cost of leisure participation clashes with the Filipino migrant workers responsibility to send remittances home. It is recommended that authorities and employers explore the importance of subjective QoL indicators such as sense of community that emerge from marginalized social groups, such as migrant workers, into their measurement systems and policy deliberations, to create a livable and sustainable community for all. Our study enriches the extant research by broadening the research location to focus on "voices" from low income migrants in a non-western context.
\end{abstract}

KEYWORDS: Leisure, quality of life, community, Filipino, migrant, migration, Macao, China

\section{Introduction}

As the 'Las Vegas of the East,' Macao has achieved rapid economic growth through its popularity as a gaming tourism destination. While tourist arrivals stood at 11.9 million in 2003, the number of annual visitors to Macao grew to 39.4 million in 2019. Macao's average income per capita/monthly increased from below 5,000 MOP (618 USD) in 2002 to 16,000 MOP (1, 976 USD) in 2018, as the unemployment rate 
decreased significantly, from 6.8 percent in 2000 to 1.9 percent in 2018 (Statistics and Census Service, 2020).

Despite the global financial crisis caused by COVID-19, political strife in Hong Kong and austerity in other parts of the globe, high wages and a low tax regime remain a strong pull to the territory, which has retained economic stability since the legalization of gambling tourism. Even with the advent of the COVID-19 pandemic, Macao's jobless rate has not risen dramatically. Due to major casino hotel development projects, Macao continues to experience a shortage of workers and continues to attract a high number of foreign migrant workers for its burgeoning gaming and hospitality sectors. Macao's population of 430,000 in 1999 increased to 679,600 by the end of 2019 , while the population of non-resident workers grew to approximately 196,538 (Statistics and Census Service, 2020), meeting the demand for low-paid jobs in construction, hospitality and domestic work (Roberts, 2004). While rigid labor regulations prohibit foreigners from working in many high salaried positions, local labor is not enough to fill positions in Macao's hotel and hospitality sectors. The hospitality sector had some 51,073 foreign workers in mid-2018 - or 28.2 per cent of total workers - employed (Wong, 2018).

While Macao's rapid economic growth and increasing foreign migrant worker numbers have raised questions as to the quality of life (QoL) of local residents, little research has focused on the migrant workers in Macao at a time of sky-rocketing living costs and other issues pertaining to QoL (Valles, 2016), such as wage inequality. A 2016 study found that the salary of lower skilled non-resident workers was approximately 6,983 MOP per month (863 USD), whilst monthly salaries for residents averaged 18,000 MOP (2,226 USD). In 2018, of 188,000 non-resident workers, mainlanders accounted for 62 percent of the total with workers from the Philippines the second-biggest imported labor segment $(31,924)$, followed by Vietnam $(15,267)$, Indonesia $(5,466)$, Hong Kong (4,578), Nepal (4,274), and Myanmar (2,540). While Macao depends on migrant workers from all over the world to sustain their economy, very few contemporary studies have investigated Filipino migrants' QoL (Shi, 2017). Even though they form the second largest migrant group, Filipinos are unlike mainland migrants who share a similar background and language to residents. Approximately $50 \%$ of Filipinos have a skilled 
person's visa to work in Macao, and they primarily work in casino hotels and hospitality, while the remainder largely arrives in Macao on domestic worker visas.

While often seen as low-skilled 'disposable' workers, Filipino migrant workers are in high demand worldwide as they often have conversational English skills, a history of familial labor migration (Maneze, Salamonson, Poudel, \& DiGiacomo, 2016) and contact with local support networks (Lueck \& Wilson, 2010). It has been suggested that these dimensions buffer Filipino migrants from the effects of acculturative stress, depression and social isolation, and make them resilient (Aukst-Margetic \& Margetic, 2005; Maneze et al., 2016; van der Ham, Ujano-Batangan, Ignacio, \& Wolffers, 2014), which can contribute to their QoL. Despite these advantages, Filipino migrants experience "acculturative stress from socioeconomic difficulties, social isolation and cultural maladjustments" (Maneze et al., 2016, p. 780) as they often leave their families behind to work abroad (Valles, 2016). They have reported loneliness and loss of social support networks, underemployment, lack of host language skills and discrimination as sources of acculturative stress (Maneze, Salamonson, Attwood, \& Davidson, 2013). As Macao visas are provided to individuals rather than families, Filipino migrant workers usually relocate alone and leave their families in the Philippines. Macao authorities do not provide health or welfare support to Filipino migrant workers. Neither do they offer Filipino language support during service delivery (e.g. with hospitality and other health services such as mental health issues) (Bernardo, Daganzo, \& Ocampoo, 2016) though the role these workers play in sustaining Macao's tourism and hospitality sector.

Migration is a global issue for societies, economies and for migrants and their families (Bahn, 2015). Subsequent research related to inflows of migrant workers is often economic (Standing, 2011) or overly focused on the impact on 'natives', with little research directed at the lives of migrant workers. Though studies indicate that mental health conditions and stress are a major issue for international migrant workers (Mendoza, Mordeno, Latkin, \& Hall, 2017), little is understood about their perceived QoL. International migrant workers often face difficulties with language barriers, emotional distress, physical distress, adjustment difficulties, lack of utilization of services, social isolation, lack of support, lack of information, cultural disparities, low economic status, unsatisfactory health care, discrimination (Kita, Minatani, Hikita, 
Matsuzaki, Shiraihi, \& Haruna, 2015), poor living conditions, and sense of insecurity and instability in daily life (Dunn \& O’Brien, 2009). Thus, issues surrounding their QoL and stress coping strategies need to be better understood, so that effective programs can be designed and made available in host societies and workplaces (Virupaksha, Kumar, \& Nirmala, 2014).

Whilst the concepts of QoL have been increasingly studied across the social sciences, many studies do not explore marginal socio-economic groups such as lowincome groups and migrant populations (Schulz, Schulte, Raube, Disouky, \& Kandler, 2018). There is little attention given to whether leisure activities and spaces enable marginalized and excluded communities and individuals to adapt to the stress and challenges encountered in their host communities/countries, thereby enhancing their QoL. Leisure is an overlooked dimension of the migrant experience (Horolets, 2012), and leisure does not feature strongly in migration studies (Meta-Codesal, Peperkamp, \& Tiesler, 2015). Likewise, the links between migrant leisure and perceived QoL are understudied.

Thus, the purposes of this study are to: (1) explore how Filipino migrant workers' experience leisure and perceive their QoL through qualitative interviews with Filipino migrant workers in Macao, (2) critically analyze their experiences, interpretation and understanding of leisure and QoL, and (3) provide insights into how leisure is related to their QoL. The findings provide recommendations for key stakeholders in government and business to support migrant workers. This study contributes to a better understanding of migrants' leisure satisfaction and the role of leisure in their QoL.

\section{Quality of Life and Migration}

Researchers use various approaches to define and measure the complex, multidimensional QoL construct. For example, social indicators, economic indices and well-being measures are all utilized, with well-being itself understood as both a synonym for and subdomain of QoL (Veenhoven, 2000). Defining QoL is challenging, as 'quality' is subjective to individuals' perceptions, feelings and cultures. A definition by the World Health Organization's QoL group has gained increasing acceptance, describing QoL as 
the individuals" "perceptions of their position in life in the context of the culture and value systems in which they live and in relation to their goals, expectations, standards and concerns" (WHOQOL Group, 1994, p. 1403). The definition includes the concern for "physical health, psychological state, personal beliefs, social relationships and their relationship to salient features of their environment" (ibid).

Researchers have recognized the complexity of QoL, given QoL indicators in one culture may not be equally important in another culture or society (Schalock, Verdugo, Jenaro, Wang, Wehmeyer, Xu, \& Lachapelle, 2005). Jenaro, Verdugo, Caballo, Balboni, Lachapelle, Otrebski, \& Schalock, 2005), for example, found that the importance of QoL indicators differed significantly across geographical groups, based on perceptions of culture-bound issues like beliefs, expectations and social policies. Schalock et al. (2005) argue that individuals in different cultures perceive themselves differently in their relationships with others, their contribution to their group and their role in society. Therefore, assumptions about happiness, well-being or life satisfaction cannot be universal, and evaluations of QoL cannot be generalized from one culture to another culture (Rapley, 2003). Verdugo, Schalock, Keith, and Stancliffe (2005) emphasize that without recognizing the potential differences among different groups, QoL research can lead to incorrect conclusions. In addition, Andereck, Valentine, Vogt, and Knopf (2007) argue that measuring the "differences and similarities between cultural groups within a given community is essential to determine QoL and the factors that contribute to QoL for all sectors of a community" (p. 485).

Thus, it is important to unravel the complex issues surrounding migrants' subjective QoL, which might be different from 'mainstream' cultures and experiences in a given country or city (Stodolska, 2017). Understanding migrants' subjective experience is key to understanding the process of migration acculturation (Porers \& Rumbaut, 1996), as migrants experience complex processes for assessing their sense of QoL and wellbeing, so as to sustain and build social resources (Bernardo et al., 2016). Migrants often have dual frames of reference in assessing their QoL (Gelatt, 2013; Vertovec, 2004). These frames emerge in "the process of changing one's values, attitudes, and behaviors as a result of sustained interaction with the people, cultural belief, and norms of the host country" (Bernardo et al., 2016, p. 280). In the process of possibly changing their values, 
attitudes, and behaviors (Gibson, 2001), migrants are exposed to cultural unfamiliarity, a sense of insecurity and instability in daily life (de Castro, Gee, \& Takeuchi, 2008; Dunn \& O’Brien, 2009; Hwang \& Ting, 2008). Economic deprivation, loneliness, isolation, poor housing conditions, racism, discrimination and sense of alienation creates and exacerbates psychological distress among migrants (Bahn, 2013). The inability to work in their chosen profession, or underemployment can impact personal self-worth, well-being (Reid, 2012) and overall QoL.

\section{Leisure, Migration, and Quality of Life}

Leisure is characterized as autonomous and self-determined (Schmalz \& Blomquist, 2016), and is framed by the ability and freedom to pursue a chosen activity (Iso-Ahola, 1997; Roberts, 2011). Meaningful and satisfactory leisure can enhance an individual's well-being and thus life satisfaction (Iwasaki \& Smale, 2009; Kim, Lee, Chun, Han, \& Heo, 2017; Schulz et al., 2018), which contributes to positive QoL (Hribernik \& Mussap, 2010; Mannell \& Kleiber, 1997). Hribernik and Mussap (2010) note that leisure should be included as a subjective well-being indicator because it is a robust life domain. Iwasaki, Messina, and Hopper (2018) identified leisure as a means to help individuals seek meaningful engagement with life, and contribute to a joyful, connected, discovered, composed and empowered life. Deschenes (2011) argues that leisure can provide a space or activity for 'healing' from everyday life and obligations/responsibilities. The liberating, meaning-making role of leisure can help individuals with life challenges and personal limitations (Deschenes, 2011). The extant literature has also demonstrated a strong association between leisure satisfaction, social connection/interaction and QoL (Helliwell \& Putnam, 2004; Foong, 1992).

As migrants often have little control over their lives, leisure can play a crucial role in developing their real and perceived agency (Hasmi, Gross, \& Scott-Young, 2014), as it may provide them a 'healing' space away from migration stress and difficulties. Indeed, ultimately, migrants may associate leisure engagement with life satisfaction (MataCodesal, Peperkamp, \& Tiesler, 2015). Korean migrants in the US, for example, demonstrated that non-participation in leisure was correlated with low life-satisfaction 
(Kim, 2000). Leisure spaces and activities enable migrants to develop, express, and negotiate their personal, social and cultural preferences (Mata-Codesal et al., 2015). Leisure can contribute to migrants' self-perception, daily life organization, a sense of self, sense of belonging (Blackshaw, 2010), and integration (Stodolska \& Alexandris, 2004). Leisure engagement can also provide a space for an expression of migrants' cultural strengths during often stressful adaptation processes (Stack \& Iwasaki, 2009).

Leisure has value for migrants because it gives people a sense of belonging and identity (Spracklen, Long, \& Hylton, 2015). Community connections, particularly, buffer individuals' psychological overloads by enhancing one's coping abilities (Kawachi \& Berkman, 2001), and equip them with competence and confidence to deal with stressors (Zhang, Liu, Li, \& Wu, 2017). As migrants often move to a host country alone without social support (Paillard-Borg \& Hallberg, 2018), they have fewer opportunities to develop strong community connections (Liu et al., 2017). Informal engagement in leisure can provide them with a platform where inclusion, recognition and belonging can be generated (Shinew, Stodolska, Floyd, Hibbler, Allison, Johnson \& Santos, 2006), and opportunities for social interactions and connections to develop.

Social connections made through leisure can increase migrants' QoL as they receive emotional support and develop a sense of belonging and emotional well-being (Helliwell \& Putnam, 2004). Likewise, connections made through leisure provide a means to seek and receive support in employment and accommodation searches. Social connections play a positive role in alleviating migrants' anxiety and engendering their positive feelings (Liu et al., 2017). For example, a study on Chinese migrants' social dance in Japan showed that "dance was obviously used as a shelter and social haven by the participants" (Liu-Farrer 2004, p. 668). Socializing can act as a refuge from social isolation and boredom (Lewis, 2015), and migrants can benefit from interactions with locals to create feelings of acceptance (Putnam, 2000). Peperkamp (2018) stressed that "even superficial interactions may be important in this regard" (p. 258). Social interactions and connections in community brought about by leisure are crucial for migrants' QoL.

However, migrants' leisure is often constrained by a lack of disposable time, a lack of finances, lack of transport, limited social connections, social status and gender 
barriers (Long, Hylton, \& Spacklen, 2014), as well as a lack of affordable and safe environments for physical leisure (Stodolska \& Shinew, 2010). Migrants' leisure constraints also include cultural differences, language barriers, insufficient access to recreation facilities, diminished family centeredness and fatigue as an outcome of working long hours (Horolets, 2012). As such, migration related difficulties can influence private lives and 'spill over' (Staines, 1980) in the form of injuries, workplace stress, exhaustion and pain, which can be major constraints to participating in leisure activities (Lenneis \& Pfister, 2017). Strenuous work conditions can make them too tired to be involved in any leisure activities besides watching TV and resting (Stodolska \& Santos, 2006). Having free time at unsociable hours diminishes the probability of having company for leisure pursuits (Long et al., 2014; Stoddolska, 2000). In addition, race and ethnicity has been identified as a leisure constraint for migrants (Spracklen et al., 2015). For example, for Mexican migrant workers in the U.S., unstructured work schedules and the resulting inability to plan in advance significantly restricted the range of leisure options (Stodolska \& Santos, 2006). African migrants in the U.K. note that a constraint on their leisure is associated with their ethnicity and their fear and experiences of prejudice. The social and cultural capital they held in their countries of origin is harder to use in the U.K. (Spracklen et al., 2015). To build productive and enjoyable lives and to have greater QoL, migrants need social assistance and connection in communities through leisure (Hasmi et al., 2014).

\section{Methods}

Most QoL studies in the social sciences use quantitative approaches. To fill a methodological gap, the researchers utilized a qualitative, exploratory and inductive approach to garner a deeper understanding of Filipino migrants' lives and their perceived QoL through their own 'voices'. This helped to explore the complexities behind existing QoL constructs, and broader issues relating to QoL and leisure. Existing QoL constructs are not fully applicable to Filipino migrants in Macao's social, economic, cultural, and environmental context. Thus, an explanatory approach, utilizing open-ended interview 
questions (Finn, Eliott-White, \& Walton, 2000) sought to "to describe [the] phenomena, in a broadest sense" (Moran, 2000, p. 4).

The researchers conducted semi-structured interviews with fourteen Filipino migrants (table 1) in January and February, 2015. As the tourism and hospitality industry is the primary employment sector for Filipino migrants, the participants were drawn from that field. The informants were approached by way of the researchers' and the research assistant's personal and professional networks, using snowball and purposive sampling (Bernard, 2006). Only informants over 18 years old and employed in tourism, hospitality and related occupations were selected. The Filipino migrant workers had to be employed under an unskilled immigration 'Blue Card' contract. The QoL and leisure of Filipino migrants were explored through their responses to open-ended questions about QoL experiences, life satisfaction, happiness, leisure satisfaction and any related issues noted by respondents. For example, participants were asked: "How would you define QoL?"; "What is an important indicator for your QoL in Macao?"; "Are you happy in Macao?"; "What do you do when you are not working?"; "How do you spend your leisure time or a day-off?"; "How do you contact and keep connected with your children/family in the Philippines?" etc. By conducting interviews, researchers attempted to "discover the meanings that participants attach to their behavior, how they interpret situations, and what their perspectives are on particular issues" (Woods, 2006, p. 2).

The first and second authors had previously lived in Macao for two years, which helped interview question construction and interpretation of the interview data. A Filipino migrant student research assistant conducted 13 interviews due to language competency and cultural familiarity with the informants, with one interview conducted by the first author in English. The semi-structured interviews were conducted in the Filipino Tagalog dialect and were fully transcribed and translated into English then back translated. All face-to-face interviews were digitally recorded with permission from the respondents and important details were noted during the interviews. Each interview took approximately forty minutes.

The interviews took place in quiet locations such as coffee shops, in the informants' home, their workplace vicinity during their break-time and in public parks. Personal information was treated with confidentiality. Although there was a list of 
questions to guide the interviewer, informants were not forced to answer any question that made them uncomfortable and respondents were urged to express their own opinions.

\section{[Inset Table 1]}

A thematic analysis was used to analyze the interview data, so as to "obtain comprehensive descriptions that provide the basis for a reflective structural analysis that portrays the essences" (Moustakas, 1994, p. 13) of the informants' experiences of QoL and leisure. The thematic analysis of the interview transcripts and researcher notes allowed the identification and creation of primary categories and themes. Following thematic analysis, the authors open coded and categorized the responses according to issues that appeared central to informants' QoL, and leisure (Attride-Stirling, 2001; Braun \& Clarke, 2001). Specifically, the researchers examined the symbolic and subjective meaning attached to the issues to which the informants referred (Suto, 1998). Each author went through the data individually and then we met several times to discuss what seemed important to participants, to find key themes. Researchers considered what kinds of content were repetitively shown in the data and what was strongly expressed from the interview transcripts. We then identified and agreed upon the key themes, which were most frequently discussed and emphasized among the informants (Ryan \& Bernard, 2003) through further discussions among the three authors. All significant statements were identified and grouped into clusters of meanings (Creswell, 2007). Relevant quotes were isolated and descriptions of these added. The analysis was guided by an iterative process that involved continual interplay between the data and background literature and expert analysis by the authors and assistants (Peters, 2010), with the themes developed from the data. The selective and interpretive nature of the interviews means that every attempt has been made to reveal a balanced assessment of the data (Ngoasong \& Kimbu, 2016).

\section{Findings and Discussion}


Based on these careful processes, we agreed with three themes that are closely related to their QoL and leisure: the importance of family/friends for QoL, a sense of community/community connectedness, and leisure satisfaction and constraints.

\section{Importance of Family \& Friends for QoL}

The informants stressed the value of family and friends as their primary foundation for QoL. Although this is a universally common value, all informants strongly stressed the importance of being with family and friends, even if family visits were shortlived. Informants identified co-presence with family and friends as important for their happiness and satisfaction with life. For example:

It [QoL] is having a complete family, instead of material things, because by the end of the day, family is the most important thing in a person's life. Material things are not forever, but family is. It is all that matters to me and that is what makes me happy.

Quality of Life? Firstly love. When I talk about love, I mean family and friends. Being surrounded with people I love and being in Macao makes it easy, it is very easy in transportation to meet your family. That's the first factor that boosts my quality of life. Anytime I can call my friends and family and I can immediately connect with them.

These findings and representative quotes aligned with prior research, (e.g. Gilbert \& Adbullah, 2004) suggesting that being with family and friends was a crucial QoL indicator.

Many informants noted that having family and connecting with friends was more important than material things. They hung out with their relatives and close Filipino friends and talked to their family back home via mobile (WhatsApp and social media) as a main leisure activity. The important role of family and friends of Filipino migrants has been reported as a primary source of support for emotional and mental health issues, given their family-oriented and collectivist cultural orientation (Maneze et al., 2016; Mossakowski, 2007; Sanchez \& Gaw, 2007). Similarly, Stodolska and Santos (2006) 
found that in the U.S., Mexican migrants' separation from families made their leisure solitary, which was reported as the most severe obstacle to their leisure engagements. Parreñas (2005) found that Filipino transitional families described how prolonged separation with migrant parents abroad affected their children in the Philippines, resulting in inadequate guardianship and failure at school.

Some of the informants in this study were mothers who left children back in the Philippines, leaving the children's grandparents as caregivers. For example, Julie (42) came to Macao to work at a restaurant, leaving two children behind with her parents in the Philippines in 2008. Julie did her parenting at a distance whilst working 12 hours per day, six days a week. When she had free time, she used WhatsApp to talk with her children and shared her activities on Facebook with her family back in the Philippines. She appreciated technology that helped her connect with her children.

But, Thank God we have technology now! So we do a video chat when I don't work. Although sometimes they prefer to watch movies and online games as they are 17 and 13.

She visited the Philippines to see her children once a year, even though the journey home is only a two-hour flight and is serviced by budget airlines. While her dream was to live with her children someday, remittance for her children's maintenance and education remain a priority for now, which confirms an economic barrier exists for many migrant workers. However, Julie does reflect on what she has missed.

Most important things for my QoL are my family, especially my children. They are my inspiration. I miss them so much... Sadly, I didn't see them growing. I visited them in the Philippines once last year, and they visited me once this year.

As the immigration policies of a receiving country strongly influence transnational family dynamics (Fresnoza-Flot, 2009), the Macao government should consider more supportive visa policies for Filipino migrants to include them as part of a sustainable community. 


\section{Sense of Community and Community Connectedness}

The informants emphasized the importance of sense of community, community connectedness, and social interactions for their QoL. Maneze et al., (2016) also found that among Filipino migrants "the role of social support networks appeared to be particularly important, as evidenced by the mitigating effects of this factor on depression and acculturative stress" (p. 784). Compared to other indicators of QoL, most informants felt strongly about the perceived lack of sense of community and lack of social connectedness in Macao. They expressed quite negative feelings about the sense of community in Macao. They did not feel welcome because of their ethnicity and did not feel a sense of belonging even though many had spent many years in Macao. Most informants also seemed concerned about social discrimination.

I don't feel like there is a sense of community in Macao. The people that I am friends with are my community, but Macao people are judgmental, biased and unfair. Even though you grew up here, you have a different nationality [ethnicity] so they don't really look at you as part of Macao community.

They could be more friendly and open-minded. To be honest people here are narrow minded. It is so much like a 'perfect plastic' world. It seems like there is a community but there's really not, what is your definition of community, it is people being united right?

... It's like we have this village mentality since this place is very small, people know each other very well, and they don't have the sense of broadening their community in a different platform so it's only a very closed community.

Communities here are like more enforced as you need to be a member or a part of something where there is a procedure on how you get to that community, wherein if I'm going to compare that in the Philippines even in a town, it will be automatic, like you are 
already part of the community by just being friends with your neighbor and helping others...People really don't stay for long ...people just come and go.

While the informants acknowledged that Macao is a diverse community, most informants experienced and perceived a poor sense of community and social connections because of cultural difficulties and social discrimination due to their ethnicity. There seemed to be an issue with community permeability and different views of how community is defined and entered.

It has been found that feelings of discrimination against their migrant status (de Castro, Fujishiro, Schweitzer, \& Oliva, 2006), and sense of alienation (Rusch \& Reyes, 2012) negatively affect QoL (Bernardo et al., 2016). However, informants who stayed longer and had a more reasonable job showed a more positive sense of community, compared to the rest. As they got to know the territory, culture and social networks, they seemed more integrated. For example:

There are many Filipino people, so we chat about what happens in the Philippines etc. Filipino community here is ...most of our Filipino fellows are friendly to each other, and they like to explore; and they are open-minded. It's also only 1-2 hour flights to Philippines from Macao, so we don't feel too far from home. I visit home at least one a year.

Macao is good for ... you know, there are Vietnamese, Korean, Thai, Portuguese... oh, culture. Macao is very nice for culture. I also tried to learn Cantonese. I have a hectic schedule so I can't go to a learning centre though.

Some of my Filipino friends go to church... When they had some problem, after work, on Sundays they go to church to talk about it. All the domestic helpers have day-off on Sundays, so they go to church.

There were different degrees of community feeling depending on how long 
informants had lived in Macao, and what kind of job they had. Overall, most of the informants did not feel there was a strong sense of community.

\section{Filipino Migrant Workers' Leisure and QoL}

Informants indicated that they had low leisure satisfaction. They believed they did not have enough leisure choices and resources, except talking to and hanging out with their Filipino friends. Some mentioned that after working extremely hard, long hours, they just wanted to rest, watched South Korean dramas and listened to music at home during their limited leisure time. Time pressures also restricted social leisure opportunities. Some were not happy about working on Sundays and not being able to go to church, which they used as a social space. This time poverty/leisure scarcity was due to their long working schedules. Many of the participants got only one day off per week, but many took a second job on their day off. This was quite a common practice among them. As breadwinners, Filipino migrant workers often try to maximize their income by seeking sideline jobs such as part-time domestic jobs (Fresnoza-Flot, 2009).

They also complained that most leisure facilities and services offered at casino hotels were overly commercialised and expensive. They noted that there were not many options to enjoy their leisure and were concerned about the lack of green spaces. For example:

...inclined to visiting hotels and casinos...everyone still tend to be inclined with activities that really bring you to the hotels and casinos, partying, drinking, gambling.

It is very small and convenient in a way it makes people stop looking for more things to do, they get satisfied with only limited things when we can all do more such as nature and sports. Since it's so small, you only think of the same routine on your day off such as just food, chilling and clubbing. 
This city has too much of a concrete jungle... They can put more and expand what we have in Coloane [the green area]. They can still put more green spaces as much as they put so many hotels.

Vong (2005) notes how many Macao residents spend their weekends on the other side of the border (in China) to eat out, go to movies and even grocery shop, as prices are much cheaper and leisure choices are more varied there than in Macao. Structural constraints (Crawford \& Godbey, 1987; Crawford, Jackson \& Godey, 1991) prevented equitable access to leisure for informants as even these leisure options were too expensive. Travelling across the border requires a visa, and a full day of travel to pass over immigration checks, which demanded too much of their limited leisure time.

The limited number of over-priced leisure facilities in Macao meant that there was not a proper and effective means ('leisure') to cope with stress. However, one positive was free access to the internet (Wi-Fi) in certain spaces in Macao, which offered remote social support. Most of the informants owned a smartphone and were able to connect to the free Wi-Fi in public spaces, libraries and casino lobbies, allowing them to connect with home. However, the public Wi-Fi and Wi-Fi offered by casinos was typically not high speed. While informants primarily had structural and interpersonal leisure constraints, the structural constraints seemed to affect their interpersonal constraints. Thus, these two noted constraints in this study are intertwined. Informants clearly needed more time off from work, as well as access to venues and opportunities for social gatherings and networking opportunities for informal social support. Given leisure opportunities and satisfaction are often associated with social interaction (Foong, 1992), and satisfaction with family, friends and partners (Balatsky \& Dierner, 1993), this pattern can negatively affect their perceived QoL.

These findings are similar to existing research, which shows that many low skilled migrants often work to the point of exhaustion (Lassetter \& Callister, 2009), with work conditions making them too tired to be involved in any leisure activities besides watching TV and resting (Stodolska \& Santos, 2006). Stodolska and Santos (2006) note that this can lead to a lack of desire to participate in leisure, which can lead to depression 
in the longer term. Mexican migrant workers' leisure in the U.S. included maintaining social contract with family and friends abroad by travelling to the home country, attending ethnic events, listening to ethnic music and watching ethnic movies (Stodolska $\&$ Santos, 2006). While informants engaged in similar practices, they did not travel back to the Philippines often (due to the financial burden) and did not attend ethnic Filipino events as Macao doesn't offer these opportunities.

However, like the community connectedness, some informants with a decent job (like the Portuguese restaurant manager) seemed to have better leisure satisfaction. Julie, for instance, liked to cook food at other Filipino relatives' houses for fun and relaxed on her day-off. For example:

There are lots of exciting things to do in Macao! I am happy in Macao! Normally on my day-off, I go out with my relatives for lunch, or visit my cousin's houses as they cook really good Filipino food! I hang out with my cousin almost every week and we have gatherings at her house, with really good Filipino food. I also try different Portuguese restaurants and foods on my day-off, so I can reflect for my own job (cooking Portuguese food). Maybe after about 5 years, I would like to start a F\&B business in the Philippines! That's my passion, I love my job, and I am happy in Macao.

Food and sharing their food have been found to provide migrants a means of affinity to create a sense of community (e.g., Caudwell, Choe, Dickinson, Lavrushkina, \& Littlejohns, 2019).

\section{Conclusions}

While exploring Filipino migrants' QoL in Macao, researchers emphasize the need to understand migrants' QoL beyond the workplace. Thus, they asked informants about their leisure, level of life satisfaction, and QoL. The study found that low-skilled Filipino migrant workers in Macao have low social status and lived and worked in Macao without their families who remain in the Philippines. We found that the informants all stressed that as family and friends were a primary element for their QoL, their absence 
reduced leisure participation and subsequent QoL. While all informants used technology to connect with family and friends in the Philippines, some distant parented through the same technologies (e.g. WhatsApp and Facebook). Informants expressed the importance of having a sense of community and community connectedness for their QoL whilst in Macao, but acknowledged that sense of community only faintly materialized. The most serious leisure constraint was a lack of leisure time due to long working hours and secondary jobs. They also noted a lack of affordable leisure options and public spaces in Macao, which negatively related to their leisure satisfaction and thus QoL. However, depending on their occupation and length of stay, their sense of community and leisure satisfaction was different. We had one informant who has become a manager at a small Portuguese restaurant, and has subsequently attained a higher income level. She was much happier with her life in Macao and built relationships with local people who were often regular restaurants' customers. She also had developed strong social networks over the 8 years whilst in Macao. Surprisingly, the Filipino informants did not draw attention to, or perceive poor public transportation, over-crowding and housing issues, which are commonly noted in the local press as problems for locals in the territory.

Even though having quality time with family and friends are a universal value for QoL, it appears to be priority among the Filipino migrants, and those were strong QoL elements compared to other factors such as living conditions, transportation issues, and their salary. As they have very little support from the government for their QoL relating to their family arrangement, this finding warrants the recommendation that governments facilitate family lives through reunification schemes and visa policies.

Community connectedness and a sense of community were important to them as well for their subjective QOL. However, all informants strongly identified a lack of community and social connectedness in Macao. In addition to a perception that there is a lack of community events and social leisure space, informants also felt discriminated in or from existing spaces. For creating a sense of community, local charities and community groups should consider organizing cultural events involving and bringing together the diverse groups in Macao. Migrants can benefit from interactions with other migrants and locals, creating feelings of acceptance (Caudwell et al., 2019; Putnam, 2000). Through cultural/ethnic events, local people might learn more about the Filipino 
culture and become familiar with them. Diverse and inclusive cultural events can also provide more leisure spaces for migrants. However, authorities should make sure migrants have shorter workdays and more equal pay to enable this kind of community participation.

Leisure programs at workplaces, for example, could motivate migrants to participate in leisure and socially interact (Lenneis \& Pfister, 2017). Casinos could offer their employees gym access or provide transport to picnic and BBQ areas on weekends. Programs that aid social gatherings, outdoor recreational activities and sporting events could enable migrants to feel more welcome, learn about other cultures, get familiar with the local systems and create opportunities for employment. Those programs can help migrants connect to different population groups in a multicultural community (Stack \& Iwasaki, 2009). In addition, migrant-focused educational programs such as workshops and seminars may help migrants plan, manage and cope with difficulties (Hasmi et al., 2014). As leisure can support migrants' physical and emotional health, and can help reduce stress, both the government and businesses could offer appropriate and accessible leisure programs.

This study contributes to the literature by broadening the geographic location of QoL research, as well as the population surrounding the topic beyond western contexts. The exploratory qualitative approach delivered a broader understanding of the topic area by representing 'voices' from migrants of low socio-economic status. The findings highlight the need for subjective QoL indicators to be used to monitor the lives of migrants and other marginalized groups, so as to create livable, sustainable and harmonious communities. Given that leisure may be experienced and interpreted differently depending on one's cultural background and socio-economic status, it was also worth exploring an under-represented and marginalized group. These findings theoretically contribute to conceptualizations of QoL across cultures, as indicators and the depth of the indicators may differ. For example, the Filipino informants showed their positive attitude towards life as a whole, which was unexpected given their relatively poor income levels, and living conditions, etc. One assumption, is that a strong faith in Catholicism supports the personal well-being concept, since it comprises of spirituality/religion along with standard of living, health, achieving in life, relationships, 
safety, community connectedness, future security, and the level of satisfaction as a whole (Khan \& Richardson, 2013). Whilst Ortiz and Arce (1986) note that when a specific population is marginalized economically, affecting their QoL, they do not necessarily have lower life satisfaction (Inglehart \& Rabier, 1986). For example, Lenneis and Pfister (2017) reported that the lack of financial resources did not appear to influence leisure participation among migrants in the Netherlands. While there is little research on crosscultural understanding of QoL and leisure, the researchers recommend future research that focuses more attention on (different) social groups as a key variable in conceptualizing QoL as well as the role of religious faith and spirituality. Given that leisure may be experienced and interpreted differently depending on cultures and socioeconomic status, more social science research is crucial to inform understanding and policy in the area of leisure choices, services and programs. As leisure choices, experiences, constraints and negotiations are not universal but depend on the intersections of gender, social class and ethnicity, more research should explore the lives and leisure patterns of marginalized groups (Lenneis \& Pfister, 2017).

It is argued that cultural perspectives of participation and constraints to participation (Dong \& Chick, 2005) should be explored further to understand and explain migrants' leisure satisfaction and how it links to their QoL. There is a need to explore how to move beyond the highly utilized hierarchical model of leisure constraints (Crawford \& Godbey, 1987; Crawford, Jackson \& Godey, 1991; Godbey, Grawford \& Chen, 2010) to consider the role of culture. Given it was developed in a Western context, Chick and Dong (2005) emphasise, for instance, how cultural constraints as an umbrella concept, influences intrapersonal, interpersonal and structural constraints. This should be considered in non-Western contexts such as the Filipino migrants' experiences in Macao.

\section{Implications}

The findings of this research offer insights into subjective QoL that can inform governments, employers and voluntary welfare organisations as they seek to manage and assist overseas migrant workers. In countries that are dependent on migrant workers, there is a growing need to better manage diversity issues and achieve community well- 
being. As globalisation creates more links with and opportunities in distant lands, subaltern communities, such as those made up of migrant workers, are increasing. This phenomenon will have to be managed not only at international level, but also at national level, as people migrate in search of better lives. Understanding and designing effective leisure programmes and support strategies will make a significant contribution to alleviating the attendant migration stress and improving QoL.

Macao's ability to attract and retain migrant workers is of paramount importance to the economy, since their inability to cope could ultimately lead to a decline in economic growth. Thus, it will be crucial to provide satisfactory leisure time and space to migrants to facilitate an enjoyable life in Macao. Consideration should be given to changing immigration law in Macao, allowing migrant workers, whose salaries prove sufficient, to bring their spouse, partner and children to live there with them. A welldefined and researched immigration law to facilitate family reunions can mitigate migration stress and improve quality of life, by reducing the sense of isolation. Migrants' salaries are often too low to pay for hospital bills, yet medical issues, even if minor, can reduce appetite and ability for leisure, increasing stress and impacting QoL. In 2020, the

Legislative Assembly rejected a trade union bill for the eleventh time, leaving all workers vulnerable to exploitation. The government should measure leisure opportunities and resources, as leisure satisfaction has a strong relationship with QoL and remove structural constraints for migrants and other marginalized populations.

\section{References}

Andereck, K. L., Valentine, K., Vogt, C., \& Knopf, R. (2007). A cross-cultural analysis of tourism and quality of life perceptions. Journal of Sustainable Tourism, 15(5), 483-500. 
Attride-Stirling, J. (2001). Thematic Networks: An Analytic Tool for Qualitative Research. Qualitative Research, 1(3): 385-405.

Aukst-Margetic, B., \& Margetic, B. (2005). Religiosity and health outcomes: review of literature. Collegium Antropologicum, 29, 365-371.

Bahn, S. (2013). Workers on 457 visas: Evidence from the Western Australian resources sector. Australian Bulletin of Labour, 39, 34-58.

Bahn, S. (2015). Managing the well-being of temporary skilled migrants, The International Journal of Human Resource Management, 26(16), 2102-2120.

Balatsky, G., \& Dierner, E. (1993). Subjective well-being among Russian students, Social Indicators Research, 28(3), 225-243.

Bernard, R. H. (2006). Research methods in anthropology: qualitative and quantitative approaches. Langam, MD: Altamira Press.

Bernardo, A. B., Daganzo, M. A., \& Ocampoo, A. C. G. (2016). Abusive supervision and well-being of Filipino migrant workers in Macau: consequences for self-esteem and heritage culture detachment, Social Indicators Research, 139(1), 277-292.

Blackshaw, T. (2010). Leisure. Key ideas. London: Routledge.

Braun, V., \& Clarke, V. (2006).Using thematic analysis in psychology. Qualitative Research in Psychology, 3(2), 77-101.

Caudwell, J., Choe, J., Dickinson, J. E., Lavrushkina, N., \& Littlejohns, R. (2019). 'Multicultural lunches': sharing food in post-Brexit south coast of England, Annals of Leisure Research. doi: 10.1080/11745398.2019.1568892.

Chick, G. E. \& Dong, E. (2005). Cultural Constraints on Leisure. In E. Jackson (Ed.), Constraints on leisure (pp. 169-183). State College, PA: Venture Publishing.

Crawford, D. W., \& Godbey, G. (1987). Reconceptualizing barriers to family leisure. Leisure sciences, 9(2), 119-127.

Crawford, D. W., Jackson, E. L., \& Godbey, G. (1991). A hierarchical model of leisure constraints, Leisure Sciences, 13(4), 309-320.

Creswell, J. W. (2007). Qualitative inquiry and research design: choosing among five approaches. Thousand Oaks: Sage.

de Castro, A. B., Fujishiro, K., Schweitzer, E., \& Oliva, J. (2006). How immigrant workers experience workplace problems: A qualitative study. Archives of Environmental \& Occupational Health, 61(6), 249-258.

de Castro, A. B., Gee, G. C., \& Takeuchi, D. T. (2008). Job-related stress and chronic health conditions among Filipino immigrants. Journal of Immigrant and Minority Health, 10(6), 551-558.

Deschenes, G. (2011). The spiritual anthropology of leisure: the homo faberreligiosus-ludens. Counselling and Spirituality/Counseling et Spiritualite, 30, 57-85.

Dong, E. \& Chick, G. (2005). Cultural Constraints on Leisure through Cross-Cultural Research. Eleventh Canadian Congress on Leisure Research, Department of Recreation and Tourism Management. Book of abstracts, 143.

Dunn, M. G., \& O’ Brien, K. M. (2009). Psychological health and meaning in life stress, social support, and religious coping in Latina/Latino immigrants. Hispanic Journal of Behavioral Sciences, 31, 204-227.

Finn, M., Eliott-White, M., \& Walton, M. (eds.) (2000). Research Methods for Leisure and Tourism Data Collection, Analysis and Interpretation. Harlow: Pearson Education. 
Foong, A. (1992). Physical exercise/sports and biopsychosocial well-being. The Journal of the Royal Society for the Promotion of Health, 112(5): 227-230.

Fresnoza-Flot, A. (2009). Migration status and transitional mothering: the case of Filipino migrants in France. Global Networks, 9(2), 252-270.

Gelatt, J. (2013). Looking down or looking up. Status and subjective well-being among Asian and Latino immigrants in the United States. International Migration Review, 47(1), 39-75.

Gibson, M. A. (2001). Immigrant adaptation and patterns of acculturation. Human Development, 44, 19-23.

Gilbert, D., \& Adbullah, J. (2004). Holidataking and the sense of well-being. Annals of Tourism Research, 31(1), 103-121.

Godbey, G., Crawford, D. W., \& Shen, X. S. (2010). Assessing hierarchical leisure constraints theory after two decades. Journal of Leisure Research, 42(1), 111-134.

Hasmi, H. M., Gross, M. J. \& Scott-Young, C. M. (2014). Leisure and settlement distress: the case of South Australian migrants, Annals of Leisure Research, 17(4): 377397.

Helliwell, J. F., \& Putnam, R. D. (2004). The social context of well-being. Philosophical Transactions of the Royal Society of London. Series B: Biological Sciences, 359, 1435-1446.

Hribernik, J., \& Mussap, A. J. (2010). Research note: Leisure satisfaction and subjective wellbeing, Annals of Leisure Research, 13(4), 701-708.

Horolets, A. (2012). Migrants' Leisure and Integration. Instytut Spraw Publicznych: Warszawa.

Hwang, W. C., \& Ting, J. Y. (2008). Disaggregating the effects of acculturation and acculturative stress on the mental health of Asian Americans. Cultural Diversity and Ethnic Minority Psychology, 14(2), 147-154.

Inglehart, R., \& Rabier, J. R. (1986). Aspirations adapt to situations-but why are the Belgians so much happier than the French? A cross-cultural analysis of the subjective quality of life. Research on the Quality of Life. Ann Arbor: Institute for Social Research University of Michigan.

Iso-Ahola, S. E. (1997). A psychological analysis of leisure and health. In Haworth, J.T. (Ed.), Work, leisure and well-being (pp. 131-144). London Routledge.

Iwasaki, Y., \& Smale, B. J. A. (2009). Longitudinal analyses of the relationships among life transitions, chronic health problems, leisure, and psychological well-being, Leisure Sciences, 20(1), 25-52.

Iwasaki, Y., Messina, E. S., \& Hopper, T. (2018). The role of leisure in meaningmaking and engagement with life, The Journal of Positive Psychology, 13(1), 29-35.

Jenaro, C., Verdugo, M. A., Caballo, C., Balboni, G., Lachapelle, Y., Otrebski, W., \& Schalock, R. L. (2005). Cross-cultural study of person-centred quality of life domains and indicators: A replication. Journal of Intellectual Disability Research, 49(10), 734-739.

Kawachi, I., \& Berkman, L. F. (2001). Social ties and mental health. Journal of Urban health, 78(3), 458-467.

Kim, M. (2000). Life satisfaction, acculturation, and leisure participation among older urban Korean immigrants, World Leisure Journal, 42(2), 28-40.

Kim, J., Lee, S., Chun, S., Han A., \& Heo, J. (2017). The effects of leisure-time physical activity for optimism, life satisfaction, psychological well-being, and positive 
affect among older adults with loneliness, Annals of Leisure Research, 20(4), 406-415.

Kita, S., Minatani, M., Hikita, N., Matsuzaki, M., Shiraihi, M., Haruna, M. (2015). A systematic review of the physical, mental, social and economic problems of immigrant women in the perinatal period in Japan, Journal of Immigrant and Minority Health, 17(6), 1863-1881.

Lassetter, J. H., \& Callister, L. C. (2009). The impact of migration on the health of voluntary migrants in Western societies: a review of the literature. Journal of Transcultural Nursing 20(1), 93-104.

Lenneis, V., \& Pfister, G. (2017). Too tired for exercise? The work and leisure of female cleaners in Denmark, Leisure Studies, 36(4), 530-541.

Lewis, H. (2015). Music, dancing and clothing as belonging and freedom among people seeking asylum in the UK. Leisure studies, 34(1), 42-58.

Liu, Y., Zhang, F., Liu, Y., Li, Z., \& Wu, F. (2017). The effect of neighbourhood social ties on migrants' subjective wellbeing in Chinese cities. Habitat International, 66, 86-94.

Lueck, K., \& Wilson, M. (2010). Acculturative stress in Asian immigrants: the impact of social and linguistic factors. International Journal of Intercultural Relations, 34, 47-57.

Liu-Farrer, G. (2004). The Chinese social dance party in Tokyo: identity and status in an immigrant leisure subculture, Journal of Contemporary Ethnography, 33, 651-673.

Long J., Hylton, K., \& Spracklen, K. (2014). Whiteness, Blackness and Settlement: Leisure and the Integration of New Migrants, Journal of Ethnic and Migration Studies, 40(11), 1779-1797.

Mata-Codesal, D., Peperkamp, E., \& Tiesler, N.-C. (2015). Editorial-Migration, migrantsand leisure: Meaningful leisure?Leisure Studies,34(1), 1-4. doi:10.1080/02614367.2015.992620

Maneze, D., Salamonson, Y., Attwood, N., Davidson, P. M. (2013). Acculturative stress in Filipino migrants with functional English: Implications for health promotion. International Journal of Culture and Mental Health, 7(1), 1-13.

Maneze, D., Salamonson, Y., Poudel, C., DiGiacomo, M. (2016). Health-Seeking Bahaviors of Filipino Migrants in Australia: The Influence of Persisting Acculturative Stress and Depression, Journal of Immigrant Minority Health, 18, 779-786.

Mannell, R., \& Kleiber, D. A. (1997). A social psychology of leisure. State College, PA: Venture Publishing.

Mendoza, N. B., Mordeno, I. G., Latkin, C. A., \& Hall, B. J. (2017). Evidence of the paradoxical effect of social network support: A study among Filipino domestic workers in China. Psychiatry Research, 255, 263-271.

Moran, D. (2000). Introduction to Phenomenology, London: Routledge.

Mossakowski, K. N. (2007). Are immigrants healthier? The case of depression among Filipino Americans. Social Psychology Quarterly, 70, 290-304.

Moustakas, C. E. (1994). Phenomenological research methods. Sage Publications, Inc.

Ngoasong, M. Z., \& Kimbu, A. N. (2016). Informal microfinance institutions and development-led tourism entrepreneurship. Tourism Management, 52, 430-439.

Ortiz, V., \& Arce, C. H. (1986). Quality of life among persons of Mexican descent. In F. M. Andrews (Ed.), Research on the quality of life (pp. 171-191). Ann Arbor: University of Michigan, Institute for Social Research.

Paillard-Borg, S., \& Hallberg, D (2018). An Analytic Journalistic Approach to the Subjective Well-Being of Filipino Women Migrant Workers in Japan, Sage Open, 8(1). 
Parreñas, R. (2005). Long distance intimacy: class, gender and intergenerational relations between mothers and children in Filipino transnational families. Global networks, 5(4), 317-336.

Peperkamp, E. (2018). 'Dutch don't dance' - leisure experiences and sense of belonging among Polish migrants in the Netherlands, Leisure Studies, 37(3), 256-267.

Peters, K. (2010). Being together in urban parks: connecting public space, leisure, and diversity. Leisure Sciences, 32(5), 418-433.

Porers, A., \& Rumbaut, R. G. (1996). Immigrant America: a portrait, University of California Press.

Putnam, R.D. (1995). Bowling Alone: America's Declining Social Capital, Journal of Democracy, 6(1), 65-78.

Putnam, R. (2000). Bowling Alone: The Collapse and Revival of American Community. New York: Simon \& Schuster/Touchstone.

Rapley, M. (2003). Quality of life research: A critical introduction. London: SAGE.

Reid, A. (2012). Under-use of migrants' employment skills linked to poorer mental health. Australian and New Zealand Journal of Public Health, 36, 120-125.

Roberts, K. (2004). The leisure industries. Basingstoke: Palgrave.

Roberts, K. (2011). Leisure: The importance of being inconsequential. Leisure Studies, $30(1), 5-20$.

Rusch, D., \& Reyes, K. (2012). Examining the effects of Mexican serial migration and family separations on acculturative stress, depression, and family functioning. Hispanic Journal of Behavioural Sciences, 35(2), 139-158.

Ryan, G.W. \& Bernard, R.H. (2003). Techniques to identify themes. Field Methods, 15(1), 85-109.

Sanchez, F., Gaw, A. (2007). Mental health care of Filipino Americans. Psychiatric Services, 58, 810-815.

Statistics and Census Service (2019). Statistics and Census Bureau: Retrieved from https://www.dsec.gov.mo/

Schalock, R. L., Verdugo, M., Jenaro, C., Wang, M., Wehmeyer, M., Xu, J., \&

Lachapelle, Y. (2005). Cross-cultural study of core quality of life indicators. American Journal on Mental Retardation, 110, 298-311.

Shi, W. (2017). Cultural Politics of emotions in Households: Migrant Domestic Workers in Macau. Inter-Asia Cultural Studies, 18 (4), 464-481.

Shinew, K. J., Stodolska, M., Floyd, M., Hibbler, D., Allison, M., Johnson, C., \& Santos, C. (2006). Race and ethnicity in leisure behavior: Where have we been and where do we need to go? Leisure Sciences, 28(4), 403-408.

Schulz, P., Schulte, J., Raube, S., Disouky, H., \& Kandler, C. (2018). The role of leisure interest and engagement for subjective well-being, Journal of Happiness Studies, 19(4), 1135-1150.

Schmalz, D. L., \& Blomquist, K. K. (2016). Time to eat: implications for leisure-based eating for health and development. In D.A. Kleiber \& F.A. McGuire (Eds.), Leisure and Human Development (pp. 189-216). Urbana, IL: Sagamore Publishing.

Stack, J. A. C., \& Iwasaki, Y. (2009). The role of leisure pursuits in adaptation processes among Afghan refugees who have immigrated to Winnipeg, Canada, Leisure Studies, 28(3), 239-259.

Staines, G. (1980). Spillover versus compensation: A review of the literature on the 
relationship between work and nonwork. Human Relations, 33, 11-129.

Standing, G. (2011). The Precariat: The new dangerous class. London: Bloomsbury Academic.

Spracklen, K., Long, J., \& Hylton, J. (2015). Leisure opportunities and new migrant communities: challenging the contribution of sport, Leisure Studies, 34(1), 114-129.

Stodolska, M., \& Santos, C.A. (2006). "Transnationalism and Leisure: Mexican Temporary Migrants in the US, Journal of Leisure Research, 38(2), 143-167.

Stodolska, M., \& Shinew, K. J. (2010). Environmental constraints on leisure time physical activity among Latino urban residents. Qualitative Research in Sport and Exercise, (2), 313-335.

Stodolska, M. (2017). Assimilation and Leisure Constraints: Dynamics of Constraints on Leisure in Immigrant Populations, Journal of Leisure Research, 30(4), 521-551.

Suto M (1998) Leisure in occupational therapy. Canadian Journal of Occupational Therapy, 65(5), 271-78.

van der Ham, A. J., Ujano-Batangan, M. T., Ignacio, R., \& Wolffers, I. (2014). Toward healthy migration: An exploratory study on the resilience of migrant domestic workers from the Philippines. Transcultural psychiatry, 51(4), 545-568.

Valles, L. (2016). Filipino workers strive to keep their familites united in Macau. Macau Daily Times. Retrieved from https://macaudailytimes.com.mo/filipino-workers-strivekeep-families-united-macau.html

Veenhoven, R. (2000). The four qualities of life, Journal of Happiness Studies, 1(1), 1-39. Verdugo, M. A., Schalock, R.L., Keith, K. D., \& Stancliffe, R. J. (2005). Quality of life and its measurement: Important principles and guidelines. Journal of Intellectual Disability Research, 49(10), 707-717.

Vertovec, S. (2004). Migrant transnationalism and modes of transformation. International Migration Review, 38(3), 970-1001. Virupaksha, H. G., Kumar, A., \& Nirmala, B. P. (2014). Migration and mental health: An interface, Journal of Natural Sceince, Biology \& Medicine, 5(2), 233-239. Vong, T. N. (2005). Leisure satisfaction and quality of life in Macao, China. Leisure Studies, 24(2), 195-207.

WHOQOL Group (1994). Development of the WHOQOL: Rationale and current status. International Journal of Mental Health, 24, 24-56.

Wong, Y. W. (2018). Macau, 180,832 foreign workers in April 2018. Macau Business. Retrieved from: http://www.macaubusiness.com/macau-180832-foreign-workers-in-april2018/

Woods, P. (2006). Successful writing for qualitative researchers. Second Edition. Oxon, UK: Routledge. 